\title{
Utilization of Bovine Blood-Rumen Digesta Mixture as Replacement for Soybean Meal and Groundnut Cake Feedstuff in Growing Pigs
}

Odukoya, S. O., Saka, A. A., Adedeji, O. Y., Akingbade, A. O. and Ijadunola, T. I. Federal College of Animal Health and Production Technology,

Moor Plantation, Ibadan.

Corresponding author: saka.azeez@gmail.com

\begin{abstract}
Mixture of bovine blood and rumen digesta (BBRDM) was evaluated for 56 days as a replacement for soybean meal (SBM) and groundnut cake (GNC) at 100\% on protein to protein basis in the diets of growing pigs to assess the nutritive value of BBRDM on the growth performance, nutrient digestibility and cost benefits. Hence, a total of 18 growing pigs were allotted on weight equalization basis into three dietary treatments consisting of six pigs per treatment in a completely randomized design. Three diets were formulated such that $T_{1}$ : served as the control diet without BBRDM but contained both soybean meal and groundnut cake. $T_{2}$ : BBRDM replaced soybean meal and $T_{3}$ : BBRDM replaced groundnut cake. Result indicated that BBRDM contained $28.65 \%$ crude protein, $13.17 \%$ ether extract, $5.26 \%$ crude fibre, $11.29 \%$ ash and $31.65 \%$ nitrogen free extract. Dietary treatments did not significantly $(P>0.05)$ influenced the growth parameters observed in this study. Although there were no significant $(P>0.05)$ difference on the nutrient digestibility parameters investigated but birds in $T_{3}$ recorded highest numerical values for crude protein (77.23), crude fibre (62.46\%), ether extract (92.33\%), nitrogen free extract $(89.61 \%)$, ash $(70.28 \%)$ and nutrient dry matter (91.67\%) while the least values were obtained from birds in $T_{1}$. Cost offeed decreased with the inclusion of BBRDM while the cost per weight gain also improved with the replacement of the conventional feed ingredients. The result also showed that an appreciable amount of money was saved when BBRDM was included in the ration of growing pigs. It is therefore concluded that BBRDM could be used as an animal protein source to compliment plant protein source such as soybean meal and groundnut cake in the diet of growing pigs.
\end{abstract}

Keywords: Pig, Bovine Blood Rumen Digesta Mixture, Groundnut cake, Soybean meal.

\section{Introduction}

The problem of food scarcity continues to plague many undeveloped countries like Nigeria as the population increases simply because the increase in population does not matched increase in food production; hence countries are always faced with inadequate supply of protein. Insufficient protein in the diet can be ascribed to many factors such as inadequate livestock feed, failure to harmonize crops with animal production, socio-cultural factors, prevalence of diseases, insects and pest infestation. These have led to non-availability of animal protein for consumption in the tropical region. More so, the availability of the world's raw material is diminishing as population grows exponentially together with the real threat of global shortage which contributes to a new awareness of the need for the re-use of materials which would have been thrown away without second thought. Originally, recycling mainly concerned the urban environmentalist but when livestock scientist discovered that poultry, and other animal wastes could in fact constitute a precious resource, inputs into this research and technology began to expand rapidly. The primary purpose of recycling is to prevent animals from competing with humans for the same food resources. Since feed costs usually 


\section{Utilization of Bovine Blood-Rumen Digesta Mixture}

represent $60-80 \%$ of the total production costs, the utilization of animal waste will inevitably lead to a significant reduction in the cost of meat, milk and other animal products. Animal wastes which include poultry manure, poultry litter, blood, bone, rumen content, cattle manure, pig manure etc when properly processed are wholesome in appearance, taste and smell and they do not have other original characteristics. Animal wastes are almost $50 \%$ higher in crude protein than the feeding ration from which they are derived. In addition they contain other basic nutrients, crude fibre, calcium, phosphorus, other minerals and trace elements, vitamins and some unidentified factors. Rumen content and blood are substantial wastes (about 50,000 and 17,000 metric tonnes available/year, respectively; Makinde, 2006) generated daily at abattoirs in Nigeria (Adeniji, 1995; Odunsi et al., 2004).

Rumen content is plant material at various stages of digestion rich in microbial protein (McDonald et al., 1990). Blood is a source of high quality protein as blood meal (80$90 \%$ crude protein high in the essential amino acids, especially lysine; NRC, 1994), and nutritional value of blood meal increases when fed in combination with other protein sources (Ilori et al., 1984; Dafwang et al., 1986). Therefore, a combination of rumen content and blood assures a potential alternative protein source. Conversion of these wastes into animal feed will increase the flexibility of ration formulation, conserve foreign exchange, and reduce environmental pollution. However, results from growth performance trials have been variable and a simple standard processing method is not available and despite previous work on such a combination as feed for poultry (Adeniji, 1995; Lien et al., 1995; Odunsi, 2003; Odunsi et al., 2004). These studies involved the heating of blood for various time-periods, but blood is sensitive to heat damage (reduction in the availability of essential amino acids due to reactions between lysine and reducing sugars; NRC, 1994). However, sun drying offers a cheaper and probably less deleterious alternative (Azad, 2008). Therefore, this study was undertaken to investigate the utilization of Bovine Blood-Rumen Digesta Mixture as replacement for soybean meal and groundnut cake feedstuff in growing pigs.

\section{Materials and methods Experimental sites}

The experiment was carried out at the piggery unit of the Teaching and Research farm of the University of Agriculture, Abeokuta, Ogun State, Nigeria $\left(7^{0} 15^{\mathrm{I}} \mathrm{N}\right.$, $\left.3^{0} 25^{\mathrm{I}} \mathrm{E}\right)$, located in the rain vegetation zone of the South Western part of Nigeria. It receives a mean rainfall of about $1,037 \mathrm{~mm}$ and the average relative humidity of about $82 \%$ throughout the year.

\section{Preparation of the experimental diet}

The rumen content and blood used for the study were collected from a nearby abattoir located at a distance of about seven kilometers from the experimental site. The blood was collected fresh into a clean bowl directly from the slaughtered cattle and was persistently steered to prevent clotting of the blood. Similarly, the rumen digesta was collected fresh immediately after opening the rumen of the slaughtered cattle, packed into a sac and pressed using a locally fabricated screw to reduce the moisture content to a considerable level. The rumen digesta was then soaked in the blood in a ratio of $2: 1$; the mixture was then dried and milled to give Bovine Blood Rumen Digesta Mixture (BBRDM). Three experimental diets were formulated with diet 1 serving as the control without the inclusion of BBRDM while diet 2 and 3 


\section{Odukoya, Saka,Adedeji, Akingbade and Ijadunola}

contained BBRDM. In diet 2, BBRDM substituted soybean meal (SBM) at $100 \%$ on protein basis. In diet $3, \mathrm{BBRDM}$ substituted groundnut cake (GNC) at 100\% also on protein basis (Table 1).

Table 1: Gross composition of experiment diets (\%)

\begin{tabular}{llll}
\hline & \multicolumn{3}{l}{ Inclusion levels of BBRDM } \\
\cline { 2 - 4 } Ingredient & $0 \%$ & $12.30 \%$ & $17.30 \%$ \\
\hline Maize & 53.00 & 53.00 & 53.00 \\
Wheat Meal & 25.00 & 20.70 & 18.70 \\
Soybean Meal & 8.00 & 0.00 & 8.00 \\
GNC & 11.00 & 11.00 & - \\
BBRDM & - & 12.30 & 17.30 \\
Bone meal & 2.00 & 2.00 & 2.00 \\
Salt & 0.05 & 0.05 & 0.05 \\
Premix & 0.05 & 0.05 & 0.05 \\
\hline Total & $\mathbf{1 0 0}$ & $\mathbf{1 0 0}$ & $\mathbf{1 0 0}$ \\
Determined Analysis & & & \\
Dry matter (\%) & 89.74 & 89.26 & 89.58 \\
Crude protein (\%) & 18.55 & 19.08 & 18.90 \\
Crude fibre (\%) & 8.96 & 7.84 & 7.81 \\
Ether extract (\%) & 4.02 & 4.14 & 4.08 \\
Ash (\%) & 9.62 & 9.96 & 9.59 \\
NFE (\%) & 48.59 & 48.24 & 49.14 \\
G.E (kcal/kg) & 4,009 & 4,079 & 4,044 \\
\hline
\end{tabular}

Experimental animals and their management

Eighteen growing pigs $(40 \pm 5 \mathrm{~kg})$ used in this study were selected from the piggery unit of the Teaching and Research Farm of the University of Agriculture Abeokuta, Ogun State. The experimental animals were distributed on weight equalization basis into three experimental groups that was replicated thrice with each group having six pigs with two 2 pigs per replicate. The experiment lasted for 10 weeks. Water and feed were supplied ad-libitum.

\section{Data collection}

\section{Growth performance}

The initial weights of the pigs were taken prior to the commencement of the experiment and were subsequently taken weekly. The daily feed intake was estimated by calculating the difference in the feed supplied and left over. The weekly weight changes were estimated by deducting the previous weight from the final weight. The market costs of the ingredients at the time of the study was used to calculate the total cost of feed per $\mathrm{kg}$ diet, total cost of feed consumed per pig and the cost per kg of weight gain.

\section{Digestibility trial}

Six pigs were assigned to each dietary treatment and were transferred into a separate metabolic cages provided with net for collection of faeces and nylon for urine collection. The animals were fed weighed amounts of concentrate diets and water was provided ad libitum. Animals were allowed seven days adaptation period and seven days excreta (faeces) collection. Subsamples of daily feed offered, refusals and faeces voided per pig were collected and weighed. At the end of collection period, the faeces collected from each pig were thoroughly mixed, to have two subsamples. One of the samples was used for estimating dry matter (DM) by ovendrying at $105^{\circ} \mathrm{C}$ for 24 hours, while the second sample was oven-dried at $60^{\circ} \mathrm{C}$ for 72 hours, milled and $10 \%$ aliquot was taken 


\section{Utilization of Bovine Blood-Rumen Digesta Mixture}

for each goat for chemical analysis.

\section{Chemical analysis}

Subsample of the experimental diet was dried at $60{ }^{\circ} \mathrm{C}$ for 24 hours and ground to pass a 1-mm sieve screen using laboratory hammer mill machine. Dry matter (DM), Ash, crude protein $\mathrm{CP}$; ( $\mathrm{N} \times 6.25)$, ether extract (EE) and crude fibre $(\mathrm{CF})$ were determined on dry samples according to the methods of AOAC. (2000).

\section{Statistical analysis}

Data collected were analyzed using oneway analysis of variance of (SAS, 2010) statistical package and the significant differences between means were compared at 5\% confidence level using Duncan multiple range tests of the same package.

\section{Results and discussion}

Indicated in Table 2 is the proximate composition of Bovine Blood-Rumen Digesta Mixture. The proximate composition of Bovine Blood-Rumen Digesta Mixture (BBRDM) showed that it contains $28.65 \%$ crude protein, $5.62 \%$ crude fibre, $13.17 \%$ ether extract, 11.29 ash and $31.65 \%$ NFE which was a sharp contrast to the values obtained by Odunsi (2003), which were $46.10 \%, 6.38 \%, 2.13 \%$, $23.40 \%$ and $16.00 \%$ for crude protein, crude fibre, ether extract, ash and Nitrogen free extract, respectively. The difference in values could be adjudged to the difference in ratio of the mixture which was 2:1 in the present study as against 1:1 mixture reported by Odunsi (2003). The disparity observed in crude protein composition values could be attributed to the type of pasture consumed by the animals and the proportion of the constituent mixtures. More so, this could be influenced by the period of fasting prior to slaughter and stage of digesta degradation in the rumen. However, the values obtained from this study agree with the values obtained by Alhassen et al. (1985) when blood and rumen content were mixed in a similar ratio of $2: 1$ which were $27.58,4.92,13.09$ and $10.78 \%$ for crude protein, crude fibre, ether extract and ash respectively. Odunsi (2003) further reported that the proximate composition of BBRDM depends on the proportion of the constituent mixtures and can also be influenced by the stage of digesta degradation in the rumen.

Table 2: Proximate Composition of Bovine Blood-Rumen Digesta Mixture

\begin{tabular}{ll}
\hline Parameters & $\%$ \\
\hline Dry matter & 90.38 \\
Crude protein & 28.65 \\
Crude fibre & 5.62 \\
Ether extract & 13.17 \\
Ash & 11.29 \\
NFE & 31.65 \\
\hline
\end{tabular}

NFE: Nitrogen free extract

Performance characteristics of growing pigs fed the experimental diet are shown in Table 3. There were no significant differences $(\mathrm{P}>0.05)$ in the parameters measured. The average daily weight gain recorded for animals in $\mathrm{T}_{1}-\mathrm{T}_{3}$ were 0.49 $\mathrm{kg} / \mathrm{d}, 0.49 \mathrm{~kg} / \mathrm{d}$ and $0.46 \mathrm{~kg} / \mathrm{d}$ respectively, with those in $\mathrm{T}_{3}$ recording the lowest value despite consuming the largest quantity of feed per week. The daily weight gain values observed decreased across the dietary treatments from $0.49 \mathrm{~kg} / \mathrm{d}$ in $\mathrm{T}_{1}$ and 2 to 0.46 $\mathrm{kg}$ in $\mathrm{T}_{3}$. On the average total weight gain, there were no significant $(\mathrm{P}>0.05)$ differences among the treatment means but numerically, the highest value $(27.34 \mathrm{~kg})$ was recorded with animals in $\mathrm{T}_{1}$ followed closely by those fed diet $2(27.16 \mathrm{~kg})$ but the 


\section{Odukoya, Saka,Adedeji, Akingbade and Ijadunola}

least value $(25.00 \mathrm{~kg})$ recorded with those fed diet 3 . This result in the present study agree with the work of Alhassan et al. (1985) who recorded a decrease in weight of ruminant animals fed BBRDM at graded levels. This was also in line with the result reported by Odunsi (2003) who observed a weight gain reduction from $12.5 \mathrm{~g} / \mathrm{bird} /$ day to as low as $2.0 \mathrm{~g} / \mathrm{bird} /$ day when BBRDM was used to replace fish meal and groundnut cake meal in layer diets. More feed were consumed by pigs in $\mathrm{T}_{3}$ which has the highest quantity of BBRDM (17.30\%) substituting $100 \%$ of GNC. The insignificant difference observed in feed intake of the pigs on BBRDM diets could be attributed to depressed appetite resulting from the unpleasant smell of the diets. Donkoh et al. (1999) and Dongmo et al. (2000) had earlier reported that the inclusion of blood meal and/ or rumen content impart obnoxious odour to the final diet and make it less palatable to birds causing a depression in consumption. In addition, the reduced feed intake with increase in the dietary BBRCM inclusion could also be due to the increase in the dietary energy concentration of the diets since birds eat to satisfy their energy requirement, they tend to attain their energy level faster with BBRDM diet (Onu, 2007; Teimouri et al., 2005). The feed conversion ratio revealed that those in $\mathrm{T}_{3}$ had the highest value (3.83) while the least value was recorded in $\mathrm{T}_{1}(3.51)$. The result of the feed conversion ratio showed a nonsignificant difference between the treatment groups. It was also observed that as the level of BBRDM increased from $12.30 \%$ in $\mathrm{T}_{2}$ to $17.30 \%$ in $\mathrm{T}_{3}$, the feed conversion values also increased as observed between those birds in $\mathrm{T}_{2}$ and $\mathrm{T}_{3}$ where an increment from 3.53 to 3.83 was. The results supported the observations of Omoniyi (2001) and Dafwang et al. (1986) who reported that as the level of metabolizable energy in the diets increases or decreases feed intake changes inversely, although the rate of adjustment is not always sufficient to keep energy intake constant.

Table 3: Performance Characteristics of Grow ing Pigs fed diets containing varying levels of Bovine Blood -Rumen Digesta Mixture

\begin{tabular}{lllll}
\hline Parameters & \multicolumn{3}{l}{ Inclusion levels of BBRDM } \\
\cline { 2 - 5 } & $0 \%$ & $12.30 \%$ & $17.30 \%$ & $\mathrm{SEM} \pm$ \\
\hline Initial weight $(\mathrm{kg})$ & 34.33 & 35.17 & 39.50 & 0.72 \\
Final weight $(\mathrm{kg})$ & 61.67 & 62.33 & 64.50 & 0.58 \\
Total weight gain $(\mathrm{kg})$ & 27.34 & 27.16 & 25.00 & 0.57 \\
Daily weight gain $(\mathrm{kg} / \mathrm{d})$ & 0.49 & 0.49 & 0.46 & 0.18 \\
Feed conversion ratio & 3.51 & 3.53 & 3.83 & 0.89 \\
Daily protein intake $(\mathrm{Kg} / \mathrm{d})$ & 0.35 & 0.36 & 0.36 & 0.08 \\
Protein efficiency ratio & 0.90 & 0.86 & 0.74 & 0.11 \\
\hline
\end{tabular}

Presented in Table 4 is the Nutrient digestibility value of growing pigs fed diet containing varying levels of BBRDM. No significant $(\mathrm{P}>0.05)$ difference was observed among the treatments for the digestibility study. Highest numerical digestibility values was obtained from pigs in $\mathrm{T}_{3}$ having crude protein $(77.23 \%)$, crude fibre $(62.46 \%)$, ether extract $(92.33 \%)$, nitrogen free extract (89.61\%), ash $(70.28 \%)$ and total digestible nutrient $(91.67 \%)$. Nutrient digestibility is an important measure of the nutritional value of feed. Since feed is basically an economic store of nutrients, its nutritional value depends partly on its digestibility. The crude protein digestibility values increased across the dietary treatment as the BBRDM 


\section{Utilization of Bovine Blood-Rumen Digesta Mixture}

increased and this increment observed was also a pointer to the fact that the lesser the crude fibre content in the diet the greater the crude protein digestibility. This result was in agreement with the report of Adegbola and Osuji (1985). Pigs in $\mathrm{T}_{3}$ had the highest digestibility values for all nutrients while those in $\mathrm{T}_{1}$ had the least values for most of the nutrients except for crude fibre where it had a higher value of $44.79 \%$ compared to $41.92 \%$ in treatment 2 .

Table 4: Nutrient digestibility (\%) of growing pigs fed diet containing varying levels of Bovine Blood-Rumen Digesta Mixture

\begin{tabular}{lllll}
\hline Parameters & \multicolumn{4}{l}{ Inclusion levels of BBRDM } \\
\cline { 2 - 5 } & $0 \%$ & $12.30 \%$ & $17.30 \%$ & SEM \pm \\
\hline Dry matter & 83.89 & 84.78 & 91.67 & 0.97 \\
Crude protein & 71.96 & 75.50 & 77.23 & 0.98 \\
Crude fibre & 44.79 & 41.92 & 62.46 & 1.35 \\
Ether & 86.00 & 88.39 & 92.33 & 0.82 \\
Nitrogen free extract & 81.44 & 83.28 & 89.61 & 0.87 \\
Ash & 48.78 & 56.43 & 70.28 & 1.23 \\
\hline
\end{tabular}

Indicated in Table 5 is the Cost benefit of feeding BBRDM to growing pigs. The cost benefit analysis obtained in this study showed that the total cost of feed $/ \mathrm{kg}$ reduced steadily from $\square 22.50$ in treatment 1 to as low as $\square 17.10$ in treatment 3 . The cost of feed $/ \mathrm{kg}$ weight gain also showed a reduction from $\square 85.72$ in treatment 1 to $\square 73.60$ in treatment 3 . It could therefore be affirmed that it was cheaper to reduce the GNC and SBM content of pig diet by substituting either of them with BBRDM in the diet. The result of the cost benefit of the inclusion of BBRDM in this study was in agreement with the reports of Odunsi (2003); Adeniji (1995); Alhassen et al. (1985); Abubakar and Yusuph (1991); Ajibosin (1998); Omoniyi (2001); and Dafwang et al.(1986).

Table 5: Cost benefit analysis of feeding varying levels of Bovine Blood-Rumen Digesta Mixture

\begin{tabular}{lllll}
\hline Parameters & \multicolumn{3}{l}{ Inclusion levels of BBRDM } \\
\cline { 2 - 5 } & $0 \%$ & $12.30 \%$ & $17.30 \%$ & SEM \pm \\
\hline Total weight gain $(\mathrm{kg})$ & 27.34 & 27.16 & 25.00 & 0.57 \\
Total feed consumed $(\mathrm{kg})$ & 104.16 & 104.72 & 106.96 & 0.50 \\
Cost of feed/kg ( $)$ & $22.50^{\mathrm{a}}$ & $20.35^{\mathrm{b}}$ & $17.10^{\mathrm{c}}$ & 0.41 \\
Total cost feed consumed/pig $(\cong)$ & $2343.60^{\mathrm{a}}$ & $2131.05^{\mathrm{b}}$ & $1829.02^{\mathrm{c}}$ & 4.18 \\
Cost of feed/weight gain $(\cong)$ & $85.72^{\mathrm{a}}$ & $78.46^{\mathrm{ab}}$ & $73.60^{\mathrm{b}}$ & 2.41 \\
\hline a,b,c & Means on the same row with different superscripts are significantly different $(\mathrm{P}<0.05)$. & &
\end{tabular}

\section{Conclusion}

The study showed that Bovine BloodRumen Digesta Mixture can successfully be used as a substitute for groundnut cake or soybean meal in the diet of growing pigs. An appreciable amount of savings could be made by using Bovine Blood-Rumen Digesta Mixture as plant protein source. Effective collections and preservations of blood and rumen content should be encouraged from all the slaughter houses across the country to ensure its availability.

\section{Acknowledgement}

The authors acknowledge the support of the management of Federal University of Agriculture Abeokuta, Ogun State, Nigeria for the animals and facilities provided for 
the study.

\section{References}

Abubakar, M. M. and Yusuph, A. O. 1991. Effectiveness of rumen content in poultry rations. Paper presented at the $16^{\text {th }}$ annual conference of NSAP Sokoto.

Adegbola, T. A. and Osuji, H. A. 1985. The effect of dietary fibre levels on dry matter intake and nutrient digestibility on the rabbit. Nigerian Journal Nutritional Science 6:113-118.

Adeniji, A. A. 1995. The value of bovine blood-rumen content meal as a feedstuff for pullets. Ph.D Thesis, University of Ilorin, Nigeria.

Ajibosin, A. A. 1998. Haematology and performance of broiler finishers fed graded levels of blood meal. M.Sc Thesis University of Ibadan, Nigeria.

Alhassan, W. S., Lufadaju, E. U. and Bello, S. A. 1985. The potential of a dry rumen content - blood mixture as feed for ruminant animals, paper presented at the $10^{\text {th }}$ Annual conference of NSAP University of Ife, Ile-ife, Nigeria.

AOAC. 2000. Association of Official Analytical Chemists, Official methods of analysis, $15^{\text {th }}$ edition. Washington D.C.

Azad, E. 2008. Design and experimental study of solar agricultural dryer for rural area. Livestock Research for Rural Development. 20:134. Retrieved September 6, 2008, $\begin{array}{llll}\mathrm{f} & \mathrm{r} & \mathrm{o} & \mathrm{m}\end{array}$ http://www.1rrd.org/1rrd/1rrd20/9/ $\operatorname{azad} 20134 . \mathrm{htm}$

Dafwang, I. I., Olomu, I., Offiong, S. A. and Bello, S. A. 1986. The effect of replacing fish meal with blood meal in the diets of laying chickens. Journal Animal

Production Research. 6:81-91.

Dongmo, T., Ngou Ngoupayou, J. D. and Pouilles Dupoix, M. 2000. Use of some local animal protein sources in the feeding of broilers. Tropicultura, 18:122-125.

Donkoh, A., Atuahene, C. C, Anang, D. M. and Ofori S. K. 1999. Chemical composition of solar dried blood meal and its effects on performance of broiler chickens. Animal Feed Science and Technology, 81: 299-307.

Ilori, J. O., Miller, E. L., Ulrey, D. E., Ku, P. K. and Hogberg, M. G. 1984. Combinations of peanut meal and blood meal as substitutes for soybean meal in corn-based growing finishing pig diets. Journal of Animal Science. 59: 394-399.

Lien, L. V., Thien, N. and Ly, L. V. 1995. By-products from food Industries: Processing and utilization for animal feed in Vietnam. ACIAR proceedings, No 68, Canberra.

Makinde, O. A. 2006. Processing of vegetable-carried bovine blood meal and its utilization by poultry and fish. P.hD. Thesis. Department of Animal Science. OAU, Ile-Ife, Nigeria.

McDonald, P., Edward, R. A. and Greenhalgh, J. F. D. 1990. Voluntary food intake. In: Animal Nutrition 4th edition. Longman Science Technology UK. Pp: 375397.

National Research Council. 1994. Nutrient Requirements of Poultry, Eighth Revised Edition. Washington, D.C.: National Academy Press.

Odunsi, A. A. 2003. Blend of Bovine 
Blood and rumen digesta as a replacement for fishmeal and groundnut cake in layer diets. International Journal of Poultry Science. 2(1): 58-61.

Odunsi, A. A., Akingbade, A. A. and Farinu, G. O. 2004. Effect of bovine blood-rumen digesta mixture on growth performance, nutrient retention and carcass characteristics of broiler chickens. Journal of Animal and Veterinary Advances, 3 (10): 663667.

Omoniyi, O. I. 2001. Nutritive value of rumen ingesta obtained from bodija Abattoir in Oyo State. B.Sc. Project, University of Ibadan, Nigeria.
Onu, P. N. 2007. The influence of heattreated sheep manure on the performance, carcass characteristics and economics of production of starter broilers. Journal of Animal and Veterinary Advances. 6(11): 1323- 1327

SAS Institute, 2010. SAS STAT software changes and enhancements, release 6.07. SAS Technical report P.229.

Teimour, A., Rezae, M., Pourreza, J., Sayyahzedch, H. and Waldroup, P. W. 2005. Effect of diet dilution in the starter period on the performance and Carcass Characteristics of Broiler Chicks. International Journal of Poultry Science 4 (12): 1006-1011.

Received: $12^{\text {th }}$ August, 2018 Accepted: $9^{\text {th }}$ February, 2019 